\title{
Penolakan Pemberian Rekomendasi Pembebanan Hak Tanggungan Terhadap Hak Guna Bangunan di atas Hak Pengelolaan Pemerintah Kalimantan Timur
}

\author{
Diera Ajeng Amalia1
}

${ }^{1}$ Fakultas Hukum Universitas Airlangga, E-mail: dira.ajeng910@gmail.com

\begin{tabular}{l}
\hline Info Artikel \\
Masuk: 26 Agustus 2018 \\
Diterima: 28 September 2018 \\
Terbit: 30 September 2018 \\
Keywords: \\
Mortgage Rights; Building \\
Rights; Management Rights \\
\\
10.24843/JMHU.2018.v07.i03. \\
p09 \\
Kata kunci: \\
Hak Tanggungan; Hak Guna \\
Bangunan; Hak Pengelolaan \\
dira.ajeng910@gmail.com \\
\\
Dorresponding Author: \\
\end{tabular}

\begin{abstract}
The aim of the study was to find out the misinterpretation in the East Kalimantan Government in the gubernatorial letter number: 593/5102 / BP-II / VI / 2012 concerning the reasons for refusing to provide recommendations for the guarantee of Underwriting Rights on Building Use Rights over the Government's East Kalimantan Management Rights. The research method used normative research (Statue Approach, legal concept analysis and Case Approach. The results of the study indicate the occurrence of misinterpretations in the Letter of the Governor of East Kalimantan Number: 593/5102 / BP-II / VI / 2012, in which the East Kalimantan Government as the Management Right holder refused to provide written recommendations or approval to the Building Use Rights owners, namely Housing residents Korpri Samarinda based on the provisions of Law Number 1 of 2004 concerning State Treasury in Article 49 paragraph (5) which states that "State / Regional Property is prohibited from being mortgaged or used as collateral for obtaining loans" is inappropriate. Because what the residents of the Samarinda Korpri Housing want to pledge is that the building is not the land where the building is a private property, keeping in mind the principle of horizontal separation in the Indonesian agrarian law.
\end{abstract}

\begin{tabular}{l} 
Abstrak \\
\hline Tujuan Penelitian adalah mengetahui kesalahan tafsir di \\
dalam Pemerintah Kalimantan Timur dalam surat \\
gubernur nomor : 593/5102/BP-II/VI/2012 mengenai \\
alasan menolak memberikan rekomendasi guna \\
penjaminan Hak Tanggungan atas Hak Guna Bangunan \\
diatas Hak Pengelolaan milik pemerintah Kalimantan \\
Timur. Metode penelitian menggunakan metode penelitian \\
normatif (The Statue Approach), pendekatan analisa \\
konsep hukum (Analitical \& Conseptual Approach), dan \\
pendekatan kasus (Case Approach). Hasil penelitian \\
menunjukan Terjadinya salah tafsir di dalam Surat \\
Gubernur Kalimantan Timur Nomor: 593/5102/BP- \\
II/VI/2012, yang mana Pemerintah Kalimantan Timur \\
sebagai pemegang Hak Pengelolaan menolak untuk \\
memberikan rekomendasi atau persetujuan tertulis \\
\hline
\end{tabular}


terhadap pemilik Hak Guna Bangunan yaitu warga Perumahan Korpri Samarinda dengan berdasar dalam ketentuan Undang-Undang Nomor 1 Tahun 2004 tentang Perbendaharaan Negara adalah kurang tepat. Karena yang ingin diagunkan oleh warga Perumahan Korpri Samarinda adalah bangunannya yang merupakan hak milik pribadi, dengan mengingat asas pemisahan horizontal yang berlaku dalam hukum agraria Indonesia.

\section{Pendahuluan}

Hak atas tanah di Indonesia terbagi menjadi 2 bagian besar, yaitu (1) Hak atas tanah yang bersifat tetap seperti Hak Milik, Hak Guna Bangunan, Hak Guna Usaha. (2) Hak atas tanah yang bersifat tidak tetap seperti Hak Tanggungan. Berdasarkan ketentuan pada Pasal 1 angka 1 Undang-Undang Nomer 4 Tahun 1996 Tentang Hak Tanggungan Atas Tanah beserta benda-benda yang berkaitan dengan tanah, Hak Tanggungan diartikan sebagai :

"Hak Tanggungan atas tanah beserta benda-benda yang berkaitan dengan tanah, yang selanjutnya disebut dengan Hak Tanggungan, adalah hak jaminan yang dibebankan pada hak atas tanah sebagaimana dimaksud dalam UUPA, berikut atau tidak berikut benda-benda lain yang merupakan satu kesatuan dengan tanah itu, untuk pelunasan utang tertentu, yang memberikan kedudukan yang diutamakan kepada kreditor tertentu terhadap kreditor-kreditor lain."

Dari rumusan Pasal 1 angka 1 Undang-Undang Hak Tanggungan tersebut dapat diketahui bahwa pada dasarnya suatu Hak Tanggungan adalah suatu bentuk jaminan pelunasan utang, dengan hak mendahului, dengan objek (jaminan)nya berupa Hak-Hak Atas Tanah yang diatur dalam Undang-Undang Nomer 5 Tahun 1960 Tentang Peraturan Dasar Pokok-Pokok Agraria atau Undang-Undang Pokok Agraria. ${ }^{1}$

Di dalam hukum jaminan bahwa sangat mungkin suatu objek Hak Tanggungan itu di eksekusi, apabila debitor melakukan wanprestasi. Pada prinsipnya setiap eksekusi harus dilakukan dengan melalui pelelangan umum, karena dengan cara ini diharapkan dapat memperoleh harga yang paling tinggi untuk objek hak tanggungan.

Hak tanggungan dapat dibebankan terhadap Hak Milik, Hak Guna Usaha, dan Hak Guna Bangunan. Hal ini sebagaimana tercantum di dalam Pasal 51 Undang-Undang Nomer 5 Tahun 1960 tentang Peraturan Dasar Pokok-Pokok Agraria, selanjutnya disingkat UUPA, yang berbunyi : "Hak Tanggungan yang dapat dibebankan pada Hak Milik, Hak Guna Usaha, dan Hak Guna Bangunan tersebut dalam Pasal 25, 33, dan 39 diatur dengan Undang-Undang". Kemudian dijelaskan pada pasal 4 Undang-Undang Nomor 4 Tahun 1996 tentang Hak Tanggungan atas tanah beserta benda-benda yang berkaitan dengan tanah, selanjutnya disingkat UUHT, objek Hak Tanggungan yaitu :

(1) Hak atas tanah yang dapat dibebani Hak Tanggungan adalah :

a. Hak Milik

b. Hak Guna Usaha

c. Hak Guna Bangunan.

${ }^{1}$ Muljadi, K., \& Widjaja, G. (2005). Seri Hukum Harta Kekayaan: Hak Tanggungan. Jakarta: Kencana. h. 13. 
(2) Selain hak-hak atas tanah sebagaimana dimaksud pada ayat (1), Hak Pakai atas tanah Negara yang menurut ketentuan yang berlaku wajib di daftar dan menurut sifatnya dapat dipindahtangankan dapat juga dibebani Hak Tanggungan.

(3) Pembebanan Hak Tanggungan pada Hak Pakai atas tanah Hak Milik akan diatur lebih lanjut dengan Peraturan Pemerintah.

(4) Hak Tanggungan dapat juga dibebankan pada hak atas tanah berikut bangunan, tanaman, dan hasil karya yang telah ada atau akan ada yang merupakan satu kesatuan dengan tanah tersebut, dan yang merupakan milik pemegang hak atas tanah yang pembebanannya dengan tegas dinyatakan di dalam Akta Pemberian Hak Tanggungan yang bersangkutan.

(5) Apabila bangunan, tanaman, dan hasil karya sebagaimana dimaksud pada ayat (4) tidak dimiliki oleh pemegang hak atas tanah, pembebanan Hak Tanggungan atas bendabenda tersebut hanya dapat dilakukan dengan penandatanganan serta pada Akta Pemberian Hak Tanggungan yang bersangkutan oleh pemiliknya atau yang diberi kuasa untuk itu oleh dengan akta otentik.

Hak Tanggungan dapat diberikan diatas hak atas tanah sebagaimana dimaksud dalam Undang-Undang Hak Tanggungan tersebut salah satunya adalah Hak Guna Bangunan. Pengertian Hak Guna Bangunan berdasarkan Pasal 35 ayat (1) UUPA yaitu "Hak Guna Bangunan adalah hak untuk mendirikan dan mempunyai bangunan-bangunan atas tanah yang bukan miliknya sendiri, dengan jangka waktu paling lama 30 tahun dan dapat diperpanjang untuk jangka waktu paling lama 20 tahun". Sedangkan pada Pasal 21 Peraturan Pemerintah Nomor 40 Tahun 1996 tentang Hak Guna Usaha, Hak Guna Bangunan, dan Hak Pakai Atas Tanah, yang selanjutnya disebut PP Nomor 40 Tahun 1996, menyebutkan bahwa tanah yang diterbitkan dengan Hak Guna Bangunan tersebut adalah Tanah Negara; Tanah Hak Pengelolaan; dan Tanah Hak Milik. Hak Guna Bangunan dapat dialihkan serta dapat dijadikan jaminan utang. Dengan demikian, maka sifat-sifat dari Hak Guna Bangunan adalah :

1. Hak untuk mendirikan dan mempunyai bangunan diatas tanah yang bukan miliknya sendiri, dalam arti dapat di atas Tanah Negara ataupun tanah milik orang lain.

2. Jangka waktu paling lama 30 tahun dam dapat diperpanjang 20 tahun lagi.

3. Dapat beralih atau dialihkan kepada orang lain.

4. Dapat dijadikan jaminan utang dengan dibebani hak tanggungan. ${ }^{2}$

Telah diketahui Hak Guna Bangunan dapat berdiri diatas tanah salah satunya yaitu tanah Hak pengelolaan. Menurut A.P. Perlindungan, secara tidak langsung pasal 2 ayat 4 UUPA menyebutkan bahwa "Hak menguasai dari negara diatas, pelaksanaannya dapat dikuasakan kepada daerah-daerah swatantra dan masyarakat-masyarakat adat, sekedar diperlukan dan tidak bertentangan dengan kepentingan nasional, menurut ketentuan-ketentuan peraturan pemerintah". Artinya bahwa hak pengelolaan adalah hak menguasai dari Negara atas tanah yang kewenangan pelaksanaannya sebagian dilimpahkan kepada pemegang haknya untuk merencanakan peruntukan dan penggunaan tanah, menggunakan tanah untuk keperluan pelaksanaan tugasnya, menyerahkan bagian-bagian tanah tersebut kepada pihak ketiga dan atau bekerja sama dengan pihak ketiga.

2 Manulang, R. (2011). Segala Hal Tentang Tanah Rumah dan Perizinannya. Jakarta: Buku Pintar. h. 20. 
Persoalan muncul terkait dengan Hak atas tanah yang bersifat tetap itu yaitu Hak Guna Bangunan tersebut yang berada diatas Hak Pengelolaan. Kreditur atau pihak Bank pada umumnya mensyaratkan kepada debitur untuk pembebanan Hak Tanggungan atas Hak Guna Bangunan yang berdiri diatas tanah Hak Pengelolaan memerlukan persetujuan tertulis atau rekomendasi, karena dari Badan Pertanahan Nasional tidak akan memproses menjadi Hak Tanggungan apabila tidak adanya rekomendasi atau persetujuan tertulis dari pemegang Hak Pengelolaan. Berdasarkan Surat Edaran Menteri Negara Agraria/ Kepala Badan Pertanahan Nasional pada tanggal 17 September 1998 No.630.1-3433, yang menyatakan bahwa dengan berpegang pada Pasal 34 ayat 7 Peraturan Pemerintah Nomor 40 tahun 1996 yang berbunyi : "Peralihan Hak Guna Bangunan atas Hak Pengelolaan harus dengan persetujuan tertulis dari pemegang Hak Pengelolaan". Peralihan tersebut memerlukan persetujuan tertulis atau rekomendasi dari pemegang Hak Pengelolaan, oleh karena dalam hal adanya kemungkinan pengalihan Hak Guna Bangunan ketika terjadi eksekusi Hak Tanggungan atas Hak Guna Bangunan yang berada diatas Hak Pengelolaan tersebut, maka persetujuan pemegang Hak Pengelolaan terhadap pembebanan Hak Guna Bangunan diatas Hak Pengelolaan itu berlaku sebagai persetujuan pengalihannya. Namun Gubernur Kalimantan Timur mengeluarkan surat gubernur nomor : 593/5102/BP-II/VI/2012 yang mana dalam surat tersebut terdapat tidak dapat dipenuhinya rekomendasi guna pembebanan Hak Tanggungan atas Hak Guna Bangunan di Perumahan Korpri Samarinda, yang berdiri diatas tanah Hak Pengelolaan milik Pemerintah Kalimantan Timur, dengan alasan bertentangan dengan ketentuan di dalam Undang-Undang Nomor 1 Tahun 2004 tentang Perbendaharaan Negara dalam Pasal 49 ayat (5) yang menyatakan "Barang Milik Negara/Daerah dilarang digadaikan atau dijadikan jaminan untuk mendapatkan pinjaman".

Tujuan Penelitian adalah mengetahui kesalahan tafsir di dalam Pemerintah Kalimantan Timur dalam surat gubernur nomor : 593/5102/BP-II/VI/2012 mengenai alasan menolak memberikan rekomendasi guna penjaminan Hak Tanggungan atas Hak Guna Bangunan diatas Hak Pengelolaan milik pemerintah Kalimantan Timur.

\section{Metode Penelitian}

Jenis penelitian dalam penyusunan penulisan ini adalah jenis penelitian normatif, Tipe penelitian yang digunakan dalam penelitian ini adalah penelitian hukum Normatif yaitu penelitian yang dilakukan dengan cara mencari pemecahan atas isu hukum yang timbul. Hasil yang hendak dicapai adalah memberikan preskripsi mengenai apa yang seyogianya. ${ }^{3}$ Jenis pendekatan yang digunakan dalam penelitian ini adalah pendekatan analisis konsep hukum (Analitical and Conseptual Approach) yaitu diawali dengan mendeskripsikan legal facts, kemudian mencari pemecahan suatu perkara hukum tertentu, penelitian ini hanya berlaku pada kasus-kasus tertentu, tujuannya bukan untuk membangun teori melainkan menguji teori yang ada pada kondisi konkret tertentu untuk menemukan hukum in concreto untuk menyelesaikan perkara hukum tertentu. ${ }^{4}$ Penelitian hukum normatif yang digunakan bersumber pada data primer dan sekunder Teknik pengumpulan bahan hukum dalam penelitian ini adalah dengan studi kepustakaan. Studi kepustakaan dilakukan dengan cara membaca, menelaah, mencatat

\footnotetext{
${ }^{3}$ Marzuki, P. M. (2010). Penelitian Hukum, Cet. Ketujuh, Jakarta: Kencana Prenada Media..h.89.

${ }_{4}^{4}$ Asikin, A.Z. (2010). Pengantar Metode Penelitian Hukum. Jakarta: Rajawali Pers. h.126.
} 
membuat ulasan bahan-bahan pustaka yang ada kaitannya dengan permasalahan hukum terkait.

\section{Hasil dan Pembahasan}

Hak Tanggungan yang dulunya dikenal dengan istilah Hypotheek merupakan suatu perbuatan hukum yang bersifat sebagai perbuatan tambahan (accesoire). Sedangkan pokoknya adalah utang piutang antara debitur dengan kreditur. Sejak disahkannya Undang-Undang Nomor 4 Tahun 1996 tentang Hak Tanggungan atas tanah beserta benda-benda yang berkaitan dengan tanah, maka khusus pada benda-benda berwujud tetapi bersifat tetap atau tidak bisa dipindahkan atau benda tak bergerak, maka penjaminannya disebut Hak Tanggungan, sehingga sebagaimana ditentukan dalam Pasal 4 UUHT menyebutkan objek Hak Tanggungan itu terdiri dari :

Ayat (1) : "Hak atas tanah yang dapat dibebani Hak Tanggungan adalah :
a. Hak milik;
b. Hak guna usaha;
c. Hak guna bangunan.;

Ayat (2) : "Selain hak-hak atas tanah sebagaimana dimaksud pada ayat (1), Hak Pakai atas tanah Negara yang menurut ketentuan yang berlaku wajib didaftar dan menurut sifatnya dapat dipindah tangankan dapat juga dibebani Hak Tanggungan".

Ayat (3) : "Pembebanan Hak Tanggungan pada Hak Pakai atas tanah Hak Milik akan diatur lebih lanjut dengan Peraturan Pemerintah".

Ayat (4) : "Hak Tanggungan dapat juga dibebankan pada hak atas tanah berikut bangunan, tanaman, dan hasil karya yang telah ada atau akan ada yang merupakan satu kesatuan dengan tanah tersebut, dan yang merupakan milik pemegang hak atas tanah yang pembebanannya dengan tegas dinyatakan di dalam Akta Pemberian Hak Tanggungan yang bersangkutan"

Ayat (5) : "Apabila bangunan, tanaman, dan hasil karya sebagaimana dimaksud pada ayat (4) tidak dimiliki oleh pemegang hak atas tanah, pembebanan Hak Tanggungan atas benda-benda tersebut hanya dapat dilakukan dengan penandatanganan serta pada Akta Pemberian Hak Tanggungan yang bersangkutan oleh pemiliknya atau yang diberi kuasa untuk itu olehnya dengan akta otentik."

Hal ini untuk membedakan perbuatan hukum terhadap benda tetap/ tidak bergerak dan benda bergerak. Creditverband dipergunakan sebagai bentuk perbuatan hukum dalam hutang piutang. Secara yuridis pengertian Hak Tanggungan sebagaimana disebut dalam pasal 1 angka 1 yang berbunyi :

"Hak Tanggungan atau tanah beserta benda-benda yang berkaitan dengan tanah, yang selanjutnya disebut Hak Tanggungan, adalah hak jaminan yang dibebankan pada hak atas tanah sebagaimana dimaksud dalam Undang-Undang Nomor 5 Tahun 1960 tentang Peraturan Dasar Pokok-Pokok Agraria, berikut atau tidak berikut benda-benda lain merupakan satu kesatuan dengan tanah itu, untuk pelunasan utang tertentu, yang memberikan kedudukan yang diutamakan kepada kreditor tertentu terhadap kreditor lain." 
Hak Tanggungan sebagaimana disebutkan dalam Pasal 1 angka 1 UUHT tersebut. Bahwa Hak Tanggungan dapat diberlakukan terhadap benda tidak bergerak sebagai penjaminan utang-piutang. Menurut Boedi Harsono, beliau berpendapat :

"Hak Tanggungan memiliki dua kedudukan istimewa pada kreditor pemegang Hak Tanggungan. Pertama, hukum perkreditan modern yang dijamin dengan Hak Tanggungan mengatur perjanjian hubungan utang piutang tertentu antara kreditor dengan debitor, yang meliputi hak kreditor untuk menjual lelang harta kekayaan tertentu yang ditunjuk secara khusus sebagai jaminan dan mengambil pelunasan piutang dari hasil penjualan tersebut jika debitor cidera janji, dan dalam mengambil pelunasan piutang dari hasil penjualan tersebut kreditor pemegang Hak Tanggungan mempunyai hak mendahului dari kreditor-kreditor yang lain (Droit De Preference). Perjanjian yang menyatakan bahwa kreditor akan memiliki objek Hak Tanggungan jika debitor cidera janji batal demi hukum. Kedua, Hak Tanggungan akan tetap membebani objek Hak Tanggungan di tangan siapapun objek Hak Tanggungan tersebut berada. Ketentuan ini, berarti bahwa kreditor pemegang Hak Tanggungan tetap berhak menjual lelang benda tersebut, biarpun sudah dipindahkan haknya kepada pihak lain (Droit De Preference)."

Dari ketentuan pasal 1 angka 1 UUHT diatas, maka unsur-unsur yang terkandung di dalamnya mengenai Hak Tanggungan yaitu :

1. Hak Jaminan atas benda tak bergerak berupa hak atas tanah

Sesuai UUPA adalah hak atas tanah seperti pada pasal 16 ayat (1) yaitu :

a. Hak milik

b. Hak guna usaha

c. Hak guna bangunan

d. Hak pakai

e. Hak sewa

f. Hak membuka tanah

g. Hak memungut hasil hutan

h. Hak-hak lain yang tidak termasuk dalam hak-hak tersebut di atas yang akan ditetapkan undang-undang serta hak-hak yang sifatnya sementara yang dimaksud dalam Pasal 53.

Dari sekian banyak hak atas tanah tersebut diatas, maka tidak semua dapat dijadikan sebagai objek hak tanggungan, karena objek Hak Tanggungan sebagaimana diatur dalam Pasal 4 ayat (1) UUHT berbunyi : "Hak atas tanah yang dapat dibebani Hak Tanggungan adalah :

a. Hak milik;

b. Hak guna usaha;

c. Hak guna bangunan."

Sedangkan hak lain yang dapat dijadikan Hak Tanggungan, sebagaimana dimaksud pada Pasal 4 ayat (2) UUHT yang berbunyi : "Selain hak-hak atas tanah sebagaimana dimaksud pada ayat (1), Hak Pakai atas tanah Negara yang menurut ketentuan yang berlaku wajib didaftar dan menurut sifatnya dapat dipindah tangankan dapat juga dibebani Hak Tanggungan". Objek Hak Tanggungan dalam pasal diatas berarti adanya Hak Tanggungan baru muncul sesaat setelah atau bersamaan dengan perjanjian pokoknya. Perjanjian pokok yang dimaksud adalah 
perjanjian utang-piutang. Sebagai alat penjamin, maka tentu saja yang mempunyai nilai yang dihitung secara nominal.

2. Sebagai alat pelunasan hutang

Perjanjian Hak Tanggungan yaitu sebagai hak tambahan (accesoire). Hal ini dapat dimaknai bahwa apabila pihak kreditor tidak memenuhi prestasi atau terjadi wanprestasi, maka dapat dilakukan eksekusi (ekskutorial) dengan catatan bahwa perjanjian terdapat irah-irah kalimat Demi Keadilan Berdasarkan Ketuhanan Yang Maha Esa. ${ }^{5}$ Pengikatan hak tanggungan bersifat accesoir artinya merupakan ikutan dari perjanjian pokok, maksudnya bahwa perjanjian hak tanggungan tersebut ada apabila telah ada perjanjian pokoknya yang berupa perjanjian yang ditimbulkan hubungan hukum utang piutang, sehingga akan hapus dengan hapusnya perjanjian pokoknya (Pasal 10 ayat (1) UUHT). Perjanjian pinjam meminjam dikonstruksikan sebagai perjanjian pokok, sedangkan pengikatan benda sebagai jaminan dikonstruksikan sebagai perjanjian tambahan atau accessoir. Apabila perjanjian pemberian kredit merupakan perjanjian pokok, yaitu perjanjian pinjam meminjam, maka pengikatan benda melalui lembaga hak tanggungan merupakan perjanjian tambahan atau yang lebih dikenal accesoir. Perjanjian pengikatan benda sebagai perjanjian accesoir adalah Sifat accesoirnya sesuai dengan sifat yang melekat pada hukum jaminan. ${ }^{6}$

Proses pembebanan hak tanggungan itu sendiri telah dijelaskan di dalam penjelasan umum angka 7 UU Nomor 4 Tahun 1996 merumuskan bahwa:

"Proses pembebanan Hak Tanggungan dilaksanakan melalui dua tahap kegiatan, yaitu:

1. Tahap pemberian Hak Tanggungan, dengan dibuatnya Akta Pemberian Hak Tanggungan oleh Pejabat Pembuat Akta Tanah, untuk selanjutnya disebut PPAT, yang didahului dengan perjanjian utang-piutang yang dijamin;

2. Tahap pendaftarannya oleh Kantor Pertanahan, yang merupakan saat lahirnya Hak Tanggungan yang dibebankan.

Berdasarkan pada rumusan pasal tersebut diketahui bahwa terdapat tiga tahap dalam pembebanan hak tanggungan yakni pembuatan perjanjian kredit oleh Bank, pembuatan Akta Pemberian Hak Tanggungan oleh PPAT, dan pendaftaran hak tanggungan pada Kantor Pertanahan. ${ }^{7}$ Sedangkan Tujuan dari Hak Tanggungan adalah untuk memberikan jaminan yang kuat bagi kreditur yang menjadi pemegang Hak Tanggungan itu untuk didahulukan dari kreditur-kreditur lain. Bila terhadap Hak Tanggungan dimungkinkan sita oleh pengadilan, maka berarti pengadilan mengabaikan, bahkan meniadakan kedudukan yang diutamakan dari kreditur pemegang Hak Tanggungan. ${ }^{8}$

\footnotetext{
${ }^{5}$ Baldruzaman, M.D. (1991). Bab-Bab Tentang Hipotek. Jakarta: Citra Aditya Bakti. h, 47.

6 Pertiwi, D. (2013). Perlindungan Hukum Pemegang Hak Tanggungan Yang Obyeknya Dikuasai Pihak Ketiga Berdasarkan Perjanjian Sewa Menyewa. Calyptra, 2(2), h. 6.

7 Yasa, W.S. A. (2017). Hak Tanggungan Atas Hak Guna Bangunan Di Atas Tanah Hak Milik, Jurnal Prasada. 4 (2). h. 87. http://dx.doi.org/10.22225/ihp.4.2.147.80-89.

8 Adrian, D. (2014). Perlindungan Hukum Terhadap Kreditur Atas Objek Hak Tanggungan Dari Upaya Sita Jaminan Oleh Pihak Ketiga. Lex Pivatum. 2(1). h.152.
} 
Di dalam hukum jaminan bahwa sangat mungkin suatu objek Hak Tanggungan itu dilakukan eksekusi, apabila debitor melakukan wanprestasi dan tidak dapat melaksanakan atas prestasinya. Berdasarkan Pasal 20 Undang-Undang Hak Tanggungan, menyatakan bahwa eksekusi Hak Tanggung dapat dilakukan dengan 2 cara, yaitu :

1. Melakukan penjualan objek hak tanggungan oleh pemegang hak tanggungan pertama atas kekuasaan sendiri melalui pelelangan umum serta mengambil pelunasan piutangnya dari hasil penjualan tersebut.

2. Melaksanakan eksekusi berdasarkan titel eksekutorial yang tercantum dalam sertipikat hak tanggungan, dalam hal ini objek hak tanggungan dijual melalui pelelangan umum menurut cara yang ditentukan dalam peraturan perundangundangan untuk pelunasan piutang pemegang hak tanggungan dengan hak mendahulu dari pada kreditor-kreditor lain.

Pada prinsipnya setiap eksekusi harus dilakukan dengan melalui pelelangan umum, karena dengan cara ini diharapkan dapat memperoleh harga yang paling tinggi untuk objek hak tanggungan.

Salah satu objek dari Hak Tanggungan adalah Hak Guna Bangunan, artinya dalam penjaminan hutang Hak Guna Bangunan bisa digunakan, Hak Guna Bangunan merupakan salah satu hak atas tanah yang duatur dalam Undang-Undang Pokok Agraria. Pengertian Hak Guna Bangunan diatur dalam Pasal 35 ayat (1) UUPA yang berbunyi : "Hak Guna Bangunan adalah hak untuk mendirikan dan mempunyai bangunan-bangunan atas tanah yang bukan miliknya sendiri, dengan jangka waktu paling lama 30 tahun dan dapat diperpanjang untuk jangka waktu paling lama 20 tahun".

Pengertian Pasal 35 ayat (1) Undang-Undang Pokok Agraria tersebut mengandung pengertian bahwa pemegang Hak Guna Bangunan bukanlah pemegang Hak Milik atas bidang tanah dimana bangunan tersebut didirikan. Sehubungan dengan hak tersebut, Hak Guna Bangunan terjadi pada tanah yang dikuasai langsung oleh Negara dan Hak Milik orang lain. Berdasarkan pada Pasal 37 UUPA yang berbunyi :

"Hak Guna Bangunan terjadi :

a. Mengenai tanah yang dikuasai langsung oleh Negara karena penetapan Pemerintah;

b. Mengenai tanah milik, karena perjanjian yang berbentuk autentik antara pemilik tanah yang bersangkutan dengan pihak yang akan memperoleh hak guna bangunan itu, yang bermaksud menimbulkan hak."

Sedangkan dalam Pasal 21 Peraturan Pemerintah Nomor 40 Tahun 1996 tentang Hak Guna Usaha, Hak Guna Bangunan, dan Hak Pakai atas Tanah menyebutkan bahwa tanah yang diterbitkan dengan Hak Guna Bangunan tersebut adalah :

a. Tanah Negara;

b. Tanah Hak Pengelolaan;

c. Tanah Hak Milik.

Namun Hak Tanggungan tidak melihat secara hukum asal mula dan dasar dari adanya Hak Guna Bangunan tersebut. Sehingga Hak Tanggungan tidak melihat apakah Hak Guna Bangunan tersebut berada diatas Tanah Hak Milik, diatas Tanah Negara, ataupun diatas Tanah Hak Pengelolaan. 
Hak Guna Bangunan dapat beralih dan dialihkan kepada pihak lain serta dapat dijadikan jaminan utang. Dengan demikian, maka sifat-sifat dari Hak Guna Bangunan adalah :

1. Hak untuk mendirikan dan mempunyai bangunan diatas tanah yang bukan miliknya sendiri, dalam arti dapat diatas Tanah Negara ataupun tanah milik orang lain.

2. Jangka waktu paling lama 30 tahun dan dapat diperpanjang 20 tahun lagi.

3. Dapat beralih atau dialihkan kepada orang lain.

4. Dapat dijadikan jaminan hutang dengan dibebani hak tanggungan. ${ }^{9}$

Hak Guna Bangunan dapat dijadikan jaminan hutang dengan dibebani Hak Tanggungan terdapat dalam Pasal 39 UUPA jo. Pasal 33 Peraturan Pemerintah Nomor 40 Tahun 19996. Adapun prosedur Hak Tanggungan atas Hak Guna Bangunan adalah

1) Adanya perjanjian utang piutang yang dibuat dengan akta notaris atau akta di bawah tangan sebagai perjanjian pokoknya.

2) Adanya penyerahan Hak Guna Bangunan sebagai jaminan utang yang dibuktikan dengan Akta Pemberian Hak Tanggungan oleh Pejabat Pembuat Akta Tanah (PPAT) sebagai perjanjian ikutan.

3) Adanya pendaftaran Akta Pemberian Hak Tanggungan kepada Kepala Kantor Pertanahan Kabupaten/ Kota setempat untuk dicatat dalam Buku Tanah dan diterbitkan Sertipikat Hak Tanggungan.

Selanjutnya terkait dengan pembebanan terhadap Hak Guna Bangunan diatas Hak Pengelolaan. Hak pengelolaan sebagai jenis hak penguasaan atas tanah lahir tidak didasarkan pada undang-undang, melainkan berdasarkan Peraturan Menteri Agraria Nomor 9 Tahun 1965. Hak pengelolaan lahir dari konversi hak penguasaan atas tanah negara. Hak pengelolaan dapat dikuasai oleh departemen-departemen, direktoratdirektorat, dan daerah-daerah swatantra. Meskipun hak pengelolaan diatur dengan Peraturan Menteri Agraria, namun hak pengelolaan mempunyai kekuatan mengikat, baik bagi pemegang hak pengelolaan maupun pihak lain yang menggunakan bagianbagian tanah hak pengelolaan. ${ }^{10}$

Pengertian Hak Pengelolaan diatur dalam Pasal 1 angka 2 Peraturan Pemerintah Nomor 40 Tahun 1996 jo Pasal 1 angka 4 Peraturan Pemerintah Nomor 24 Tahun 1997 tentang pendaftaran tanah yaitu "Hak Pengelolaan adalah hak menguasai negara yang kewenangan pelaksanaannya sebagian dilimpahkan kepada pemegangnya". Pengertian lebih lengkap tentang hak pengelolaan dinyatakan dalam Pasal 2 ayat (3) Undang-Undang Nomor 2 Tahun 2000 tentang Perubahan Atas Undang-Undang Nomor 21 Tahun 1997 tentang Bea Perolehan Hak Atas Tanah dan Bangunan jo Pasal 1 Peraturan Pemerintah Nomor 112 Tahun 2000 tentang Pengenaan Bea Perolehan Hak Atas Tanah dan Bangunan karena Pemberian Hak Pengelolaan, yaitu Hak Pengelolaan adalah hak menguasai dari negara atas tanah yang kewenangan pelaksanaannya

\footnotetext{
${ }^{9}$ Manulung, R, Op.cit, h. 20.

10 Santoso, U. (2008). Pengaturan Hak Pengelolaan. Jurnal Media Hukum, 2(2).
} 
sebagian dilimpahkan kepada pemegang haknya untuk merencanakan peruntukan dan penggunaan tanah, menggunakan tanah untuk keperluan pelaksanaan tugasnya, menyerahkan bagian-bagian tanah hak pengelolaan kepada pihak ketiga dan atau bekerja sama dengan pihak ketiga.

Pergeseran subjek Hak Pengelolaan terjadi antara pasal dan Penjelasan dalam UUPA. Perbedaan Pasal 2 ayat (4) dan Penjelasan UUPA cukup dramatis. Pasal 2 ayat (4) hanya menyebut 2 (dua) subjek Hak Pengelolaan yaitu daerah swatantra dan masyarakat hukum adat. Pada Penjelasan Subjek Hak Pengelolaan tiba-tiba muncul kata "Departemen", sedangkan kata-kata "masyarakat hukum adat" hilang. Dengan demikian secara yuridis antara pasal dan Penjelasan UUPA tidak sinkron, dalam memaknai subjek Hak Pengelolaan, ada yang "dikembangkan" dan ada bagian yang "dihilangkan". Dalam dinamikanya subjek Hak Pengelolaan makin meluas ke badan profit pemerintah yakni Badan Usaha Minim Negara dan Badan Usaha Milik Daerah. ${ }^{11}$ Subjek atau pemegang Hak Pengelolaan adalah sebatas pada badan hukum Pemerintah baik yang bergerak dalam bidang bisnis, seperti Badan Usaha Milik Negara/ Badan Usaha Milik Daerah, PT Persero, badan hukum swasta tidak mendapatkan peluang untuk berperan sebagai subjek atau pemegang Hak Pengelolaan. Hak Pengelolaan diberikan kepada badan hukum yang seluruh atau sebagian modalnya berasal dari pemerintah atau pemerintah daerah badan hukum tersebut mempunyai tugas pokok dan fungsinya berkaitan dengan pengelolaan tanah.

Pada Pasal 21 Peraturan Pemerintah Nomor 40 Tahun 1996 menyatakan bahwa tanah yang diterbitkan dengan Hak Guna Bangunan salah satunya dapat terbit diatas tanah Hak Pengelolaan. Maria S.W. Sumardjono menyatakan bahwa untuk memperoleh Hak Guna Bangunan diatas Hak Pengelolaan, pihak ketiga harus memperoleh persetujuan dari pemegang hak pengelolaan yang dimuat dalam perjanjian penyerahan, penggunaan dan pengurusan hak atas tanah, karena perjanjian itu merupakan alas hak pemberian hak guna bangunan di atas Hak Pengelolaan. Pihak ketiga yang memperoleh Hak Guna Bangunan atau Hak Pakai yang berasal dari bagian-bagian tanah Hak Pengelolaan melalui perjanjian penggunaan tanah antara pemerintah daerah sebagai pemegang Hak Pengelolaan dengan pihak ketiga. Sebagaimana tercantum di dalam ketentuan pada Pasal 4 ayat (2) Peraturan Menteri Negara Agraria/ Kepala Badan Pertanahan Nasional No. 9 Tahun 1999 menetapkan bahwa hubungan hukum antara pemegang hak pengelolaan dengan pihak ketiga dalam mempergunakan tanah hak pengelolaan dibuat dengan perjanjian penggunaan tanah. Dalam ketentuan ini tidak menentukan perjanjian penggunaan tanah harus dibuat dengan akta notariil atau akta di bawah tangan. Menurut Endang Purwaningsih, suatu perjanjian dinyatakan sah apabila memenuhi 4 (empat) syarat kumulatif, yaitu: sepakat di antara mereka yang mengi- katkan diri; kecakapan untuk membuat suatu perikatan; suatu hal tertentu (adanya hak dan kewajiban para pihak); suatu sebab yang

${ }^{11}$ Rahmi, E. (2010). Eksistensi Hak Pengelolaan Atas Tanah (HPL) dan Realitas Pembangunan Indonesia. Jurnal Dinamika Hukum, 10(3), h. 351. 
halal (tidak bertentangan dengan ketertiban umum, kesusilaan, dan undangundang). ${ }^{12}$

Pihak ketiga dapat memperoleh Hak Guna Bangunan atau Hak Pakai yang berasal dari tanah Hak Pengelolaan melalui perjanjian build, operate, and transfer (bot). Maria S.W. Sumardjono mendefinisikan perjanjian BOT sebagai perjanjian antara dua pihak, dimana pihak pertama menyerahkan penggunaan tanahnya, untuk didirikan suatu bangunan diatasnya oleh pihak kedua, dan pihak kedua berhak mengoperasikan atau mengelola bangunan tersebut dalam jangka waktu tertentu, dengan memberikan fee atau tanpa fee kepada pihak pertama, dan pihak kedua wajib mengembalikan tanah beserta bangunan di atasnya dalam keadaan dapat dan siap dioperasikan kepada pihak pertama setelah jangka waktu operasional berakhir. ${ }^{13}$

Sedangkan untuk Pembebanan Hak Tanggungan diatas tanah Hak Pengelolaan, Hak Pengelolaan tidak dapat dijadikan objek jaminan hutang. Karena Hak Pengelolaan bukan merupakan hak yang bersifat privat, namun hanya merupakan hak yang bersifat publik. Pemegang Hak Pengelolaan, tidak dapat menjaminkan Hak Pengelolaan yang dikuasai sebagai agunan atas suatu hutang. Tetapi yang dapat dibebani dengan hak jaminan adalah hak-hak atas tanah yang berdiri di atas Hak Pengelolaan, yaitu Hak Milik, Hak Guna Bangunan, Hak Guna Usaha, dan Hak Pakai, sedangkan Hak Pengelolaannya sendiri tidak dapat dibebani hak jaminan.

Dalam hukum agraria menganut Asas Pemisahan Horizontal yaitu suatu asas yang memisahkan antara pemilikan hak atas tanah dengan benda-benda atau bangunanbangunan yang berada di atasnya. Dalam penerapannya asas pemisahan horizontal mengandung dua segi, yaitu segi hukum dan segi kepemilikan bangunannya. Segi hukumnya adalah bahwa atas pemisahan horizontal memisahkan hukum yang berlaku antara tanah dengan bangunan. Apabila berkaitan dengan tanah, maka tunduk pada hukum tanah pertanahan dan apabila berkaitan dengan bangunan, maka tunduk pada hukum perutangan. Sedangkan segi kepemilikan bangunan adalah bahwa asas pemisahan horizontal memisahkan antara pemilik tanah dengan pemilik bangunan. ${ }^{14}$ Sehingga Pemerintah tidak bisa menganggap bahwa benda-benda atau bangunan-bangunan yang berada diatas tanah Hak Pengelolaan merupakan aset negara/daerah juga karena baik dari segi hukum maupun segi kepemilikannya itu berbeda.

Penerapan asas pemisahan horizontal adalah konsekuensi dari dimasukkannya unsur hukum adat ke dalam hukum pertahanan nasional. Dimana, asas pemisahan horizontal adalah kebalikan dari asas pelekatan yang mengatakan bangunan dan tanaman merupakan satu kesatuan dengan tanah. Sebaliknya, asas pemisahan horizontal menyatakan bangunan dan tanaman bukan merupakan bagian dari tanah. Sehingga konsekuensinya hak atas tanah tidak dengan sendirinya meliputi

12 Endang, P. (2011). Penegakan Hukum Jabatan Notaris Dalam Pembuatan perjanjian Berdasarkan Pancasila dalam Rangka Kepastian Hukum. 2(3). h. 332.

13 Sumardjono, M. S. (2008). Tanah dalam perspektif hak ekonomi, sosial, dan budaya. Jakarta: Penerbit Buku Kompas. h.208.

14 Soerodjo, I. (2014). Hukum pertanahan hak pengelolaan atas tanah (HPL): eksistensi, pengaturan, dan praktik. Yogyakarta: Laksbang Mediatama. h. 51. 
kepemilikan bangunan dan tanaman yang ada di atasnya. Berdasarkan asas pemisahan horizontal, dimungkinkan dalam satu bidang tanah yang sama terdapat beberapa hak kepemilikan atas tanah secara bersamaan. Jadi dalam sebidang tanah, ada dua hak yang melekat, yaitu :Hak primer adalah hak milik (individu ataupun hak menguasai negara), dan hak sekunder (Hak Pakai, Hak Pengelolaan, Hak Guna Bangunan, Hak Guna Usaha, dan lain-lain). ${ }^{15}$

Tata cara atau prosedur pembebanan Hak Tanggungan atas Tanah yang berada diatas tanah Hak Pengelolaan pada dasarnya sama dengan peralihan (jual beli) tanah diatas tanah Hak Pengelolaan, yaitu dilakukan dengan memohon ijin atau persetujuan dan membayar uang pemasukan/ biaya administrasi kepada pemegang Hak Pengelolaan. Ketentuan mengenai peralihan, pembebanan dan pelepasan Hak Pengelolaan biasanya dicantumkan dalam syarat-syarat yang tertuang dalam Surat Keputusan Pemberian Hak. Bisa juga dalam perjanjian pemberian hak yang diterbitkan oleh pemegang Hak Pengelolaan kepada pihak ketiga yang memanfaatkan atau menggunakan tanah tersebut.

Sebelum tanah dan/atau bangunan diatas Hak Pengelolaan diagunkan/ dijaminkan kepada kreditur (bank atau lembaga keuangan non bank). Pemegang hak atas tanah yang bertindak selaku debitur dan/ atau penjamin wajib mengajukan permohonan terlebih dahulu kepada pemegang Hak Pengelolaan guna mendapatkan ijin. Pemberian ijin untuk menjaminkan tanah atau hak atas tanah diatas Hak Pengelolaan tersebut juga dimaksudkan sebagai upaya kontrol dari pemegang Hak Pengelolaan, termasuk agar tidak terjadi penyimpangan terhadap tanah yang dijaminkan tersebut. Di samping itu juga sebagai upaya kontrol kepada pemegang tanah atau hak atas tanah yang akan menjaminkan agar tetap menjaga tanah yang diagunkan tidak dieksekusi apabila terjadi kemacetan kredit. ${ }^{16}$

Terkait dengan hal tersebut, sesuai dengan ketentuan di dalam Pasal 34 Peraturan Pemerintah Nomor 40 Tahun 1996, yang berbunyi :

Ayat (1) : "Hak Guna Bangunan dapat beralih dan dialihkan kepada pihak lain."

Ayat (2) : "Peralihan Hak Guna Bangunan terjadi karena :
a. Jual beli;
b. Tukar Menukar;
c. Penyertaan dalam modal;
d. Hibah;
e. Pewarisan.

Ayat (3) : :Peralihan Hak Guna Bangunan sebagaimana dimaksud dalam ayat (2) harus didaftarkan pada Kantor Pertanahan."

Ayat (4) : :Peralihan Hak Guna Bangunan karena jual beli kecuali jual beli melalui lelang, tukar menukar, penyertaan dalam modal, dan hibah harus dilakukan dengan akta yang dibuat oleh Pejabat Pembuat Akta Tanah."

Ayat (5) : "Jual beli yang dilakukan melalui pelelangan dibuktikan dengan Berita Acara Lelang."

\footnotetext{
15 Ante, S. (2015). Penerapan Asas Pemisahan Horizontal terhadap Kepemilikan Hak Atas Tanah di Kota Manado. Lex et Societatis. 3(6). h.81

16 Soerodjo, I. Op.cit. h. 108.
} 
Ayat (6) : "Peralihan Hak Guna Bangunan karena pewarisan harus dibuktikan dengan surat wasiat atau surat keterangan waris yang dibuat oleh instansi yang berwenang."

Ayat (7) : "Peralihan Hak Guna Bangunan atas tanah Hak Pengelolaan harus dengan persetujuan tertulis dari pemegang Hak Pengelolaan."

Ayat (8) : "Peralihan Hak Guna Bangunan atas tanah Hak Milik harus dengan persetujuan tertulis dari pemegang Hak Milik yang bersangkutan."

Sesuai isi Pasal 34 ayat (7) diatas tersebut berarti untuk peralihan Hak Guna Bangunan diatas Hak Pengelolaan itu harus dengan persetujuan tertulis atau rekomendasi dari pemegang Hak Pengelolaan. Pembebanan Hak Guna Bangunan diatas Hak Pegelolaan sesuai dengan yang tertera pada Surat Menteri Negara Agraria/ Kepala Badan Pertanian Nasional pada tanggal 17 September 1998 No. 630. 1-3433. Dalam surat tersebut pada nomor 2 dituliskan sebagai berikut :

"Maka dalam kaitan dengan kemungkinan dibebankannya Hak Tanggungan pada Hak Guna Bangunan atas tanah Hak Pengelolaan dapat dijelaskan sebagai berikut :

a. Sesuai dengan ketentuan dalam UUPA maupun Undang-Undang Hak Tanggungan (UU Nomor 4 Tahun 1996) Hak Guna Bangunan atas tanah Hak Pengelolaan dapat dibebani Hak Tanggungan;

b. Dalam Pasal 34 Peraturan Pemerintah Nomor 40 Tahun 1996 tentang ditentukan bahwa peralihan Hak Guna Bangunan atas tanah Hak Pengelolaan memerlukan persetujuan tertulis dari pemegang Hak Pengelolaan. Sehubungan dengan itu mengingat kemungkinan dialihkan Hak Guna Bangunan tersebut dalam rangka eksekusi Hak Tanggungan, maka pembebanan Hak Tanggungan atas Hak Guna Bangunan itu juga memerlukan persetujuan tertulis dari pemegang Hak Pengelolaan yang akan berlaku sebagai persetujuan untuk peralihannya apabila kemudian diperlukan dalam rangka eksekusi Hak Tanggungan."

Berdasarkan Surat Menteri Agraria tersebut, maka surat persetujuan dari pemegang Hak Pengelolaan yang diberikan kepada pemegang hak atas tanah memiliki dua fungsi sekaligus, yaitu:

a. Sebagai persetujuan untuk melakukan tindakan penjaminan (mengagunkan) tanah dan/ atau bangunan; dan

b. Sebagai persetujuan pengalihan tanah dan/ atau bangunan kepada pihak lain apabila terjadi eksekusi Hak Tanggungan sebagai akibat kemacetan hutang/kredit. ${ }^{17}$

Pada tanggal 26 Juni 2012, Gubernur Kalimantan Timur mengeluarkan surat dengan nomor : 593/5102/BP-II/VI/2012, yang di dalam surat tersebut pemerintah Kalimantan Timur tidak dapat atau menolak untuk memberikan rekomendasi tertulis bagi pemegang Hak Guna Bangunan di Perumahan Korpri Samarinda. Pemerintah Kalimantan Timur menafsirkan bahwa tidak dapat dipenuhinya untuk memberikan rekomendasi terhadap pemilik Hak Guna Bangunan milik masyarakat di Perumahan Korpri yang berdiri diatas tanah Hak Pengelolaan Pemerintah Kalimantan Timur, yang mana Hak Guna Bangunan tersebut akan dibebankan dengan Hak Tanggungan dengan alasan bertentangan dengan ketentuan di dalam Undang-Undang Nomor 1 Tahun 2004 tentang Perbendaharaan Negara dalam Pasal 49 ayat (5) yang menyatakan

17 Ibid. 
"Barang Milik Negara/Daerah dilarang digadaikan atau dijadikan jaminan untuk mendapatkan pinjaman". Sehingga warga pemilik Hak Guna Bangunan di Perumahan Korpri Samarinda tersebut, merasa dirugikan karena tidak dapat membebankan bangunan atau rumah mereka dengan Hak Tanggungan, karena tidak mendapat rekomendasi dari Pemerintah Kalimantan Timur.

Sebagaimana telah Penulis jelaskan diatas bahwa pihak bank (kreditor) mensyaratkan bahwa untuk dibebankannya Hak Tanggungan atas Hak Guna Bangunan yang berdiri diatas tanah Hak Pengelolaan diperlukannya rekomendasi atau persetujuan tertulis dari pemegang Hak Tanggungan dalam kasus ini yaitu Pemerintah Kalimantan Timur. Dengan berdasarkan Surat Menteri Negara Agraria/ Kepala Badan Pertanian Nasional pada tanggal 17 September 1998 No. 630. 1-3433 yang menyatakan untuk pembebanan Hak Tanggungan pada Hak Guna Bangunan atas tanah Hak Pengelolaan memerlukan persetujuan tertulis dari pemegang Hak Pengelolaan yang akan berlaku sebagai persetujuan tertulis dari pemegang Hak Pengelolaan yang akan berlaku sebagai persetujuan untuk peralihannya apabila kemudian diperlukan dalam rangka eksekusi Hak Tanggungan. Mengingat bahwa akan dimungkinkannya terjadi wanprestasi yang dilakukan debitor. Karena wanprestasi tersebut maka pihak kreditor mempunyai hak untuk mengeksekusi terhadap objek jaminan Hak Tanggungan milik debitor. Dengan cara sebagaimana dijelaskan di dalam Pasal 20 Undang-Undang Hak Tanggungan, yang untuk selanjutnya akan di alihkan dengan jual beli melalui pelengan umum.

Menurut penulis mengenai alasan penolakan untuk memberikan rekomendasi yang dilakukan Pemerintah Kalimantan Timur kepada pemegang warga pemilik Hak Guna Bangunan di Perumahan Korpri Samarinda dengan alasan bertentangan dalam Undang-Undang Nomor 1 Tahun 2004 pada Pasal 49 ayat (5) adalah kurang tepat. Karena yang dimaksud di dalam pasal tersebut adalah "Barang Milik Negara/Daerah", dalam hal ini berarti tanah Hak pengelolaan milik pemerintah Kalimantan Timur yang mana merupakan hak milik publik, sedangkan dalam kasus ini yang ingin warga tanggungkan adalah bangunannya yang dibebani Hak Guna bangunan yang mana merupakan hak milik privat warga sendiri. Serta dengan mengingat asas pemisahan horizontal yang berlaku di dalam hukum agraria bahwa antara tanah dan bangunan tidak dapat dipersamakan. Sehingga Pemerintah Kalimantan Timur tidak bisa menganggap bahwa benda-benda atau bangunanbangunan yang berada diatas tanah Hak Pengelolaan merupakan aset negara/daerah juga karena baik dari segi hukum maupun segi kepemilikannya itu berbeda. Dalam hal ini jelas bahwa Pemerintah Kalimantan Timur merugikan warga Perumahan Korpri samarinda, karena tidak dapat membebankan Hak Tanggungan diatas Hak Guna Bangunan milik warga tersebut.

\section{Kesimpulan}

Terjadinya salah tafsir di dalam Surat Gubernur Kalimantan Timur Nomor: 593/5102/BP-II/VI/2012, yang mana Pemerintah Kalimantan Timur sebagai pemegang Hak Pengelolaan menolak untuk memberikan rekomendasi atau persetujuan tertulis terhadap pemilik Hak Guna Bangunan yaitu warga Perumahan Korpri Samarinda dengan berdasar dalam ketentuan Undang-Undang Nomor 1 Tahun 2004 tentang Perbendaharaan Negara dalam Pasal 49 ayat (5) yang menyatakan “Barang Milik Negara/Daerah dilarang digadaikan atau dijadikan jaminan untuk 
mendapatkan pinjaman" adalah kurang tepat. Karena yang ingin diagunkan oleh warga Perumahan Korpri Samarinda adalah bangunannya bukan tanahnya yang mana bangunan tersebut merupakan hak milik pribadi, dengan mengingat asas pemisahan horizontal di yang berlaku di dalam hukum agraria Indonesia.

\section{Daftar Pustaka}

Buku

Asikin, A.Z. (2010). Pengantar Metode Penelitian Hukum. Jakarta: Rajawali Pers.

Baldruzaman, M.D. (1991). Bab-Bab Tentang Hipotek. Jakarta: Citra Aditya Bakti.

Manulang, R. (2011). Segala Hal Tentang Tanah Rumah dan Perizinannya. Jakarta: Buku Pintar.

Marzuki, P. M. (2010). Penelitian Hukum, Cet. Ketujuh, Jakarta: Kencana Prenada Media.

Muljadi, K., \& Widjaja, G. (2005). Seri Hukum Harta Kekayaan: Hak Tanggungan. Jakarta: Kencana.

Soerodjo, I. (2014). Hukum pertanahan hak pengelolaan atas tanah (HPL): eksistensi, pengaturan, dan praktik. Yogyakarta: Laksbang Mediatama.

Sumardjono, M. S. (2008). Tanah dalam perspektif hak ekonomi, sosial, dan budaya. Jakarta: Penerbit Buku Kompas.

\section{Artikel Jurnal}

Adrian, D. (2014). Perlindungan Hukum Terhadap Kreditur Atas Objek Hak Tanggungan Dari Upaya Sita Jaminan Oleh Pihak Ketiga. Lex Pivatum. 2(1). 144155.

Ante, S. (2015). Penerapan Asas Pemisahan Horizontal terhadap Kepemilikan Hak Atas Tanah di Kota Manado. Lex et Societatis. 3(6). 79-88.

Endang, P. (2011). Penegakan Hukum Jabatan Notaris Dalam Pembuatan perjanjian Berdasarkan Pancasila dalam Rangka Kepastian Hukum. 2(3). 323-335.

Pertiwi, D. (2013). Perlindungan Hukum Pemegang Hak Tanggungan Yang Obyeknya Dikuasai Pihak Ketiga Berdasarkan Perjanjian Sewa Menyewa. Calyptra, 2(2), 116.

Rahmi, E. (2010). Eksistensi Hak Pengelolaan Atas Tanah (HPL) dan Realitas Pembangunan Indonesia. Jurnal Dinamika Hukum, 10(3), 339-348.

Santoso, U. (2008). Pengaturan Hak Pengelolaan. Jurnal Media Hukum, 2(2).

Yasa, W.S. A. (2017). Hak Tanggungan Atas Hak Guna Bangunan Di Atas Tanah Hak Milik, Jurnal Prasada. 4 (2). 80-89. http://dx.doi.org/10.22225/jhp.4.2.147.80-89 


\section{Peraturan Perundang-undangan}

Undang-Undang Nomor 5 Tahun 1960 Tentang Peraturan Dasar Pokok-Pokok Agraria (Lembaran Negara Republik Indonesia Tahun 1960 Nomor 104, Tambahan Lembaran Negara Republik Indonesia Nomor 2043).

Undang-Undang Nomor 4 Tahun 1996 Tentang Hak Tanggungan atas Tanah Beserta Benda-Benda yang Berkaitan dengan Tanah (Lembaran Negara Republik Indonesia Tahun 1996 Nomor 42, Tambahan Lembaran Negara Republik Indonesia Nomor 3632).

Undang-Undang Nomor 2 Tahun 2000 tentang Perubahan Atas Undang-Undang Nomor 21 Tahun 1997 tentang Bea Perolehan Hak Atas Tanah dan Bangunan (Lembaran Negara Republik Indonesia Tahun 2000 Nomor 130, Tambahan Lembaran Negara Nomor 3988).

Undang-Undang Nomor 1 Tahun 2004 tentang Pembendaharaan Negara (Lembar Negara Republik Indonesia Tahun 2004 Nomor 5, Tambahan Lembaran Negara Republik Indonesia Nomer 4355)

Peraturan Pemerintah Nomor 40 Tahun 1996 Tentang Hak Guna Usaha, Hak Guna Bangunan, dan Hak Pakai Atas Tanah.

Peraturan Pemerintah Nomor 24 Tahun 1997 tentang Pendaftaran Tanah.

Peraturan Menteri Negara Agraria/Kepala Badan Pertanahan Nasional Nomor 9 Tahun 1999 tentang Tata Cara Pemberian dan Pembatalan Hak Atas Tanah Negara dan Hak Pengelolaan

Peraturan Pemerintah Nomor 112 Tahun 2000 tentang Pengenaan Bea Perolehan Hak Atas Tanah dan Bangunan karena Pemberian Hak Pengeloaan.

Peraturan Menteri Agraria/ Kepala Badan Pertanahan Nasional Nomor 9 Tahun 1999 Tentang Tata Cara Pemberian dan Pembatalan Hak Atas Tanah Negara dan Hak Pengelolaan.

Surat Menteri Negara Agraria/ Kepala BPN No. 630.1-3433, Hak Tanggungan Atas Hak Guna Bangunan Di Atas Tanah Hak Pengelolaan, tanggal 17 September 1998.

Surat Gubernur Kalimantan Timur Nomor : 593/5102/BP-II/VI/2012, tentang perpanjangan dan pemberian rekomendasi atau persetujuan tertulis. 